\title{
Policy Implementation Study on Spatial Planning for Environmental Conflict (Study Location: Rembang Regency)
}

\author{
Indraya Kusyuniadi ${ }^{1, *}$ \\ ${ }^{1}$ Master Program of Environmental Science, School of Postgraduate Studies, Diponegoro University, Semarang, Indonesia
}

\begin{abstract}
This study aims to see the impact and benefits as an outcome of a policy, where this policy is in the form of spatial planning (Regional Planning). As known RTRW is a product that can be regarded as "the book of development" in every region both in the provincial and regional levels. One of them is as a decision tool for investors (investors) in increas ing local development investment, spatial planning (RTRW) is also expected to maintain the environment, in order to support the sustainability of regional development. In reality, there are still many conflicts of interest in the implementation process of regional development, especially between economic and environmental interests. Often the interests of regional sustainability are placed at a lower level (less priority) than investment / economy. Land conversion that is inconsistent with district / city spatial planning RTRW is relatively still occurring, especially for economic purposes. Lack of policy called spatial plan in this case RTRW Province and Regency in responding to existing condition in field. How can a product that is said to be "Scripture" a regional planning is powerless in fulfilling the space for investment in the form of industry, commercial, housing and so forth. There are several results that can be concluded in this study. Basically, the importance of the environment at least can be used as the basis or priority of the main decision makers above economic interests and other politic interests. The current Spatial Plan / RTRW document still holds a big question whether at the time of compilation it follows the norms and rules in a plan (data accuracy, through input process from the community).
\end{abstract}

\section{Preliminary}

\subsection{Background}

Based on the contents of Law No. 32/2009 (UUPPLH) Chapter I on General Provisions, Article 1 point 1 Definition of the environment: "The environment is the unity of space with all objects, power, situations, and living things, including humans and their behavior, Nature itself, the survival of life, and the welfare of human beings and other living beings. "The need for a document in the form of Strategic Environmental Assessment (KLHS) becomes very important because it is a" Tool "instrument for the prevention of pollution / environmental damage.

While spatial planning is a multi-sectoral activity, in accordance with the mandate of Law no. 26 of 2007 on Spatial Planning, and Government Regulation No. 15 of 2010 on Spatial Planning mentioned that, in the implementation of spatial planning there are three main processes that are interconnected with one another, namely spatial planning, space utilization, and spatial use control. Spatial planning material is contained in Law Number 26 Year 2007 on Spatial Planning, in one of its articles (35). Space utilization control is carried out through the establishment of zoning regulations, licensing, incentives and disincentives, and the imposition of sanctions.

Increasing population and the growing influence of private sector investment, triggering more rapid land use changes that can trigger a variety of environmental conflicts is a conflict between exploitation and destruction. The solution is to assume that natural resources are public goods. A category of goods that are considered to belong together, the numbers are fixed, and free.

In fact, spatial planning (RTRW) is a legal product as outlined in the Regional Regulation (Perda) which is expected to become a tool in sustainable regional development still encountered obstacles so as to create a conflict of space. Non-compliance with the existing condition is marked by the shift of conservation function land for industry, housing, agriculture etc.

\subsection{Problems}

Based on the above description, the occurrence of sectoral interest is the economic sector (investment) with the environmental sector as a limiting factor in the perspective of regional development. These conditions need to be viewed and studied in depth in policies and rules. The question of why there should be a conflict and a shift in the function of space, if every region already has a "Holy Book" called RTRW, which is a tool for 
distributing space legally, let alone this document is equipped with Strategic Environmental Assessment (KLHS).

Some of the existing problems that occurred in the District of Rembang, Kebumen Regency associated with the conflict of space between the industry and protected areas. This conflict has long dragged on to much energy consuming both socially, economically and politically. Another problem is the shifting of other protected functions into cultivation areas. In addition, the current policy is the time to evaluate the RTRW document with the adjustment of the pattern of space.

To address the above problems this study will attempt to describe chronologically the policies and events, identifying them as part of the analysis process. In addition, in this study also the data of land change especially on protected land (preservation), where in its presentation can also be analyzed will deviation of land at district RTRW with existing condition through "Time Series" data.

\section{Design and location research}

To examine the implementation of policy in the District RTRW in this study was conducted two (2) the scale of the research location, namely: 1) the scale of the area is the plan of the cement industry area and 2) the regional scale that changes the pattern of land use in the period 2009-2015.

a. Research design

1) Stages of data inventory in the form of:

- Inventory of existing policies and regulations at national, provincial and local levels.

- Inventory of numerical and spatial data (area and map statistics) in time series (Year 20092015).

- Excavation of data through observation and interviews measurable with several sources of information.

2) Reviewing and assessment:

- Policy or rules, through chronological description and analysis.

- The pattern of land change through time series data (Year 2009-2015), by looking at future trend and projection.

- The pattern of deviation of existing land with RTRW Disctrict, by looking at future trends and projections.

b. Research sites Location

In this study will take the location on the scale of the area of Gunem sub District Rembang sub District and regional scale in Rembang regency.

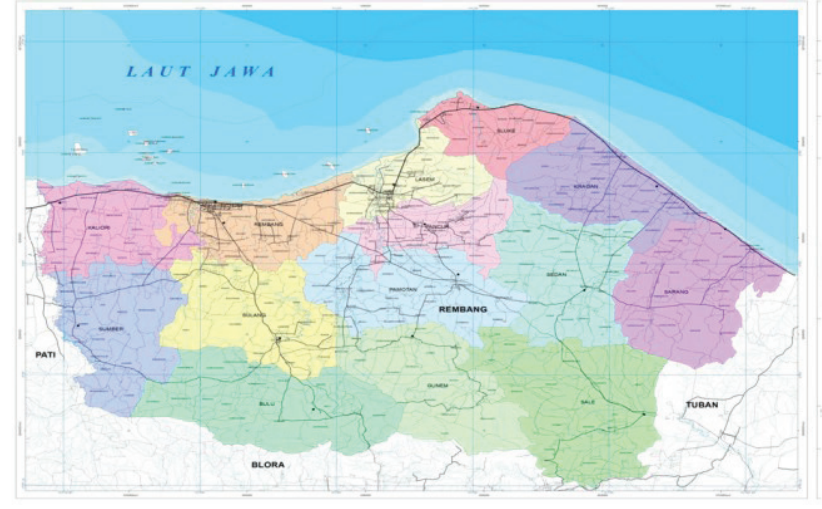

Fig. 1. Map of administration of Rembang Regency

\section{Results}

\subsection{Policy and regulatory data}

1) Decision of Rembang Regent Number 545/68/2010 About Provision of Mining Business License (WIUP) for Tras Exploration to PT Semen Gresik (Persero) Tbk - from 20 December 2012 to PT Semen Indonesia (Persero) Tbk

2) Decision of Rembang Regent Number 545/4/2011 About Mining Business License (IUP) Exploration on PT Semen Gresik (Persero) Tbk Name - since December 20, 2012 to PT Semen Indonesia (Persero) Tbk;

3) Decision of Rembang Regent Number 591/040/year 2011 On the Granting of Location Permit to PT Semen Gresik (Persero) Tbk, from 20 December 2012 to PT Semen Indonesia (Persero) Tbk for the Construction of Cement Plant, Raw Material Mine and Other Supported Facilities;

4) Decree of the Governor of Central Java Number 660.1/10 Tahun 2012 On the Environmental Feasibility of Mining Plans and Construction of Cement Plant by PT Semen Gresik (Persero) Tbk, in Rembang Regency, Central Java Province dated June 7, 2012;

5) Decree of the Governor of Central Java Number 660.1/17 year 2012 About Concerning Environmental Permit for Mining Activities by PT Semen Gresik (Persero) Tbk, in Rembang Regency, Central Java Province dated June 7, 2012;

6) Decision of Rembang Regent Number 545/0230/2013 About the Granting of Mining Business License (IUP) of Clay Rock Production Operation at PT Semen Gresik (Persero) Tbk;

7) Civil Court of Justice (PTUN) Semarang, Central Java On Thursday (16/04/2015) again held a trial lawsuit residents of Rembang with the agenda of reading a decision related to the granting of environmental permits by the Governor of Central Java for mining and the establishment of PT Semen Indonesia factory in Rembang. Decided not to accept the lawsuit of citizens. 
8) Re-review (PK) proposed by Rembang farmers and NGO Wahana Lingkungan Indonesia (Walhi), related to the environmental permit for PT Semen Indonesia's factory construction in Rembang. The Supreme Court (MA) granted the Decree, making the environmental permit issued by Central Java Governor for PT Semen Indonesia to be canceled (Based on decision number $99 \mathrm{PK} / \mathrm{TUN} / 2016,5$ October 2016).

Regulation and other supporting rules, including:

1) The Constitution of the Republic of Indonesia Law Number 26 of 2007 concerning Spatial Planning;

2) The Constitution of the Republic of Indonesia Number 32 of 2009 on Environmental Protection and Management;

3) Minister of the Environment Regulation No. 27 of 2009 On Guidelines for the Implementation of Strategic Environmental Assessment

4) Regional Regulation province of Central Java Number 6 of 2010 Concerning Regional Spatial Plan of Central Java Province of 2009 - 2029;

5) Regional Regulation Regency of Rembang Number 14 of 2011 About Spatial Plan of Rembang Regency Year 2011-2031;

\subsection{The potential of nature in the Kendeng Mountains}

The location of a quarry that has the potential to build a Cement Plant is located in Gunem District of Rembang Regency where this area / region is part of Kendeng Mountains. The North Kendeng mountains range from Kudus Regency to Tuban Regency, including Grobogan, Blora, Pati and Rembang districts. The North Kendeng mountains are batuk Hills. Hills that have undergone natural processes within geological space and time limits. The phenomenon of the Karst North Kendeng Landscape is reflected through the numerous limestone hills of the cones, the emergence of springs in rock fractures, the flowing of underground rivers with cave corridors as their corridors [1].

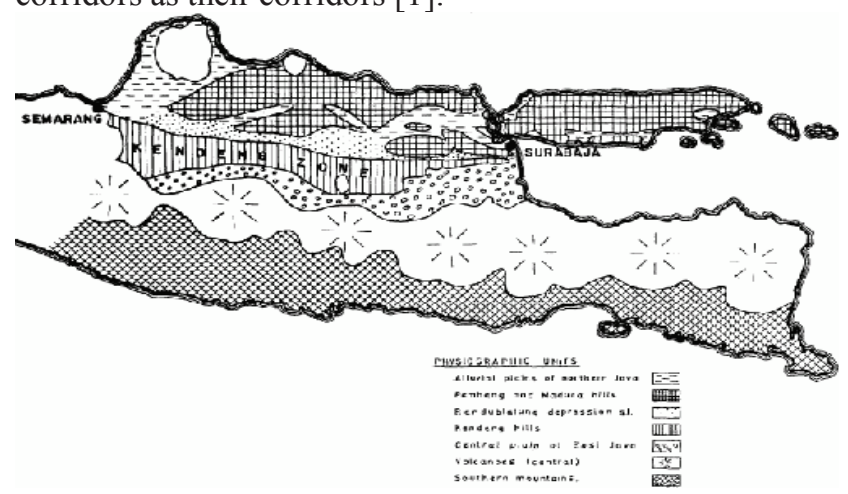

Fig. 2. Photographic Sketch of East Java Island [2]

The Kendeng zone is also often called Kendeng Mountains and those who call it Kendeng Deep, is a west-east anticlinorium. In the north bordering Depression Randublatung, while the southern part of the ranks of volcanoes (Zone Solo). The Kendeng Zone is a continuation of the North Serayu Mountain Zone that develops in Central Java. Mandala Kendeng stretches from Salatiga to the east to Mojokerto and plunges beneath the Brantas River alluvial, the continuation of these mountains can still be followed to the bottom of the Madura Strait.

\subsection{Data of Land Area Year 2009 - 2015}

Based on data from the Regional Public Work Water Resources and Spatial Planning (DCKTR) Province of Central Java Year 2016 shows there is a shift in the area of land between the period of 2009-2015, with details in the table below [3].

Table 1. Land area based on land use classification Year 2009

\begin{tabular}{|l|r|}
\hline \multicolumn{1}{|c|}{ Land Use Classification 2009 } & \multicolumn{1}{c|}{ Area (Ha) } \\
\hline Industry and Tourism & 113.65 \\
\hline Kebun / plantation & $32,407.40$ \\
\hline Lahan Berhutan / Forested Land & 844.93 \\
\hline Lahan Terbuka / Open field & 173.75 \\
\hline Perairan / Waters & $2,650.90$ \\
\hline Perkebunan / Plantation & $20,965.80$ \\
\hline Settlement & $5,616.11$ \\
\hline Dryland Agriculture & $5,108.73$ \\
\hline Rice fields & $33,462.50$ \\
\hline Semak Belukar / Shrubs & $2,090.86$ \\
\hline Total Area & $103,434.63$ \\
\hline
\end{tabular}

Table 2. Land area based on land use classification Year 2015

\begin{tabular}{|l|r|}
\hline \multicolumn{1}{|c|}{ Land Use Classification 2015 } & \multicolumn{1}{c|}{ Area (Ha) } \\
\hline Industry and Tourism & 144.84 \\
\hline Kebun / plantation & $29,873.20$ \\
\hline Lahan Berhutan / Forested Land & 838.33 \\
\hline Lahan Terbuka / Open field & 162.53 \\
\hline Perairan / Waters & $2,607.06$ \\
\hline Perkebunan / Plantation & $20,606.30$ \\
\hline Settlement & $10,962.50$ \\
\hline Dryland Agriculture & 149.88 \\
\hline Rice fields & 133.04 \\
\hline Semak Belukar / Shrubs & $35,949.60$ \\
\hline Total Area & $2,007.49$ \\
\hline Industry and Tourism & $103,434.78$ \\
\hline
\end{tabular}

\subsection{Data deviation of existing land with RTRW}

Existing land area of the data Year 2015 with map RTRW Province Year 2009-2029. For 6 years the data on land deviation with the RTRW document obtained data as in table 3 . 
Table 3. Area of land deviation Existing with spatial planning

\begin{tabular}{|l|l|r|}
\hline $\begin{array}{c}\text { Land Classification } \\
\text { RTRW }\end{array}$ & $\begin{array}{c}\text { The Land Classification } \\
\text { of Existing Year 2015 }\end{array}$ & $\begin{array}{c}\text { The area } \\
\text { of land } \\
\text { deviation } \\
\text { (Ha) }\end{array}$ \\
\hline $\begin{array}{l}\text { Physiographic } \\
\text { Protected Areas }\end{array}$ & Industry and Tourism & 625.50 \\
\hline Wetland Farming Area & Industry and Tourism & $3,184.47$ \\
\hline $\begin{array}{l}\text { Dryland Agricultural } \\
\text { Area }\end{array}$ & Industry and Tourism & 958.41 \\
\hline $\begin{array}{l}\text { Area of Hard Crop } \\
\text { Agriculture }\end{array}$ & Industry and Tourism & 106.21 \\
\hline Rural & Industry and Tourism & $2,719.09$ \\
\hline Nature preserve & plantation & 77.68 \\
\hline Protected forest & plantation & $9,619.94$ \\
\hline Rural & plantation & $28,973.40$ \\
\hline Urban & plantation & $2,668.47$ \\
\hline
\end{tabular}

\begin{tabular}{|l|l|r|}
\hline \multicolumn{1}{|c|}{$\begin{array}{c}\text { Land Classification } \\
\text { RTRW }\end{array}$} & $\begin{array}{c}\text { The Land } \\
\text { Classification of } \\
\text { Existing Year 2015 }\end{array}$ & $\begin{array}{c}\text { The area of } \\
\text { land } \\
\text { deviation } \\
\text { (Ha) }\end{array}$ \\
\hline Rural & Forested Land & $3,542.57$ \\
\hline Protected forest & Perkebunan & $11,946.30$ \\
\hline Protected forest & Settlement & $2,206.35$ \\
\hline Production forest & Settlement & $11,469.90$ \\
\hline Limited production forest & Settlement & $6,848.70$ \\
\hline Wetland Farming Area & Settlement & $185,401.00$ \\
\hline Dryland Agricultural Area & Settlement & $87,481.90$ \\
\hline Production forest & Open Mining & 40.04 \\
\hline Limited production forest & Open Mining & 45.14 \\
\hline Dryland Agricultural Area & Open Mining & 322.49 \\
\hline Protected forest & Dryland Agriculture & $2,106.61$ \\
\hline Protected forest & Rice fields & $2,286.17$ \\
\hline Wetland Farming Area & Settlement & $185,401.00$ \\
\hline Dryland Agricultural Area & Settlement & $87,481.90$ \\
\hline
\end{tabular}

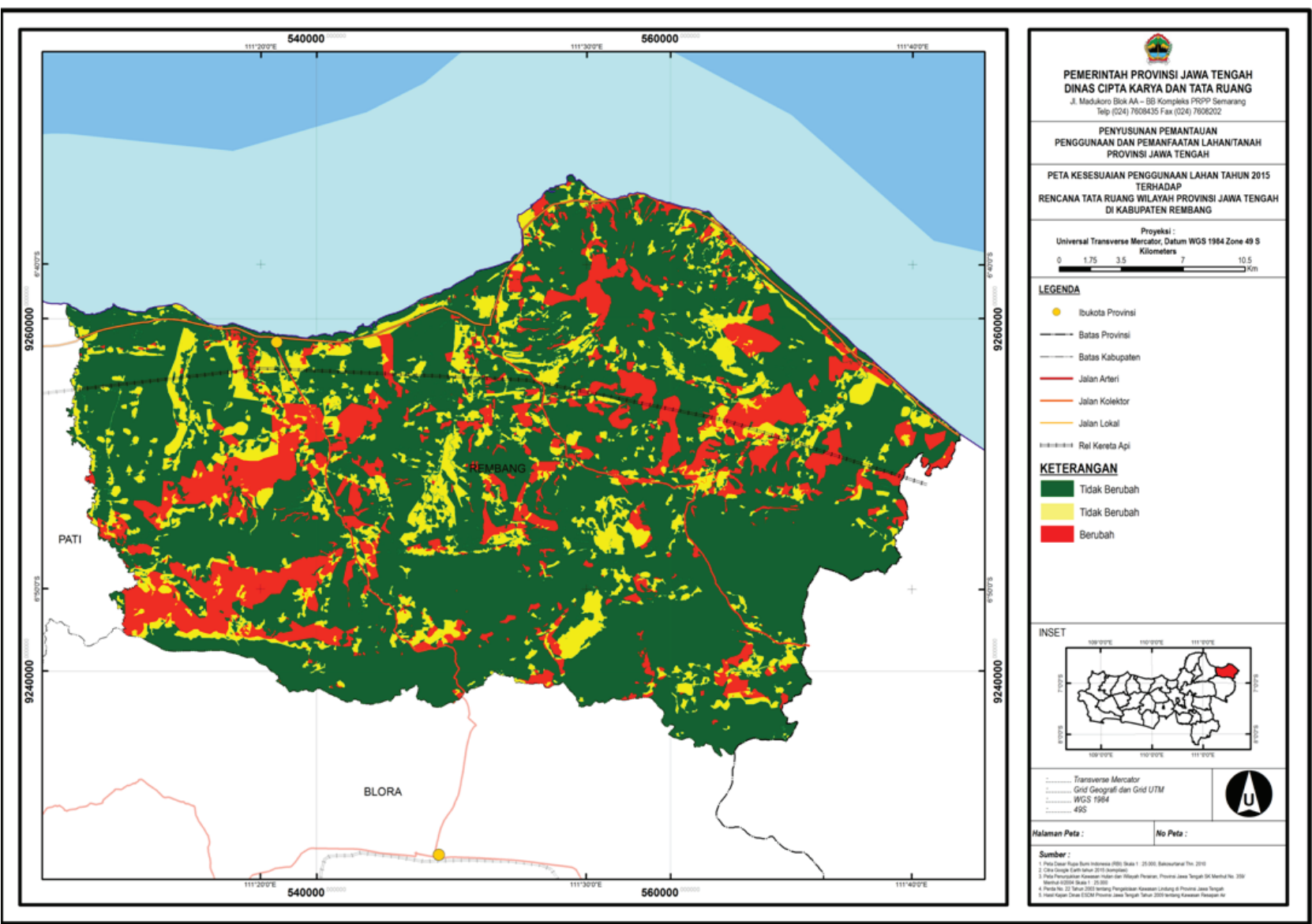

Fig. 2. Map of existing land deviation with RTRW [3].

\section{Review of the study}

\subsection{Policy Review}

Keep in understanding the problems arising digging today, that is by describing will chronologically be the cement plant (decision number 99 PK/TUN/2016), including: 


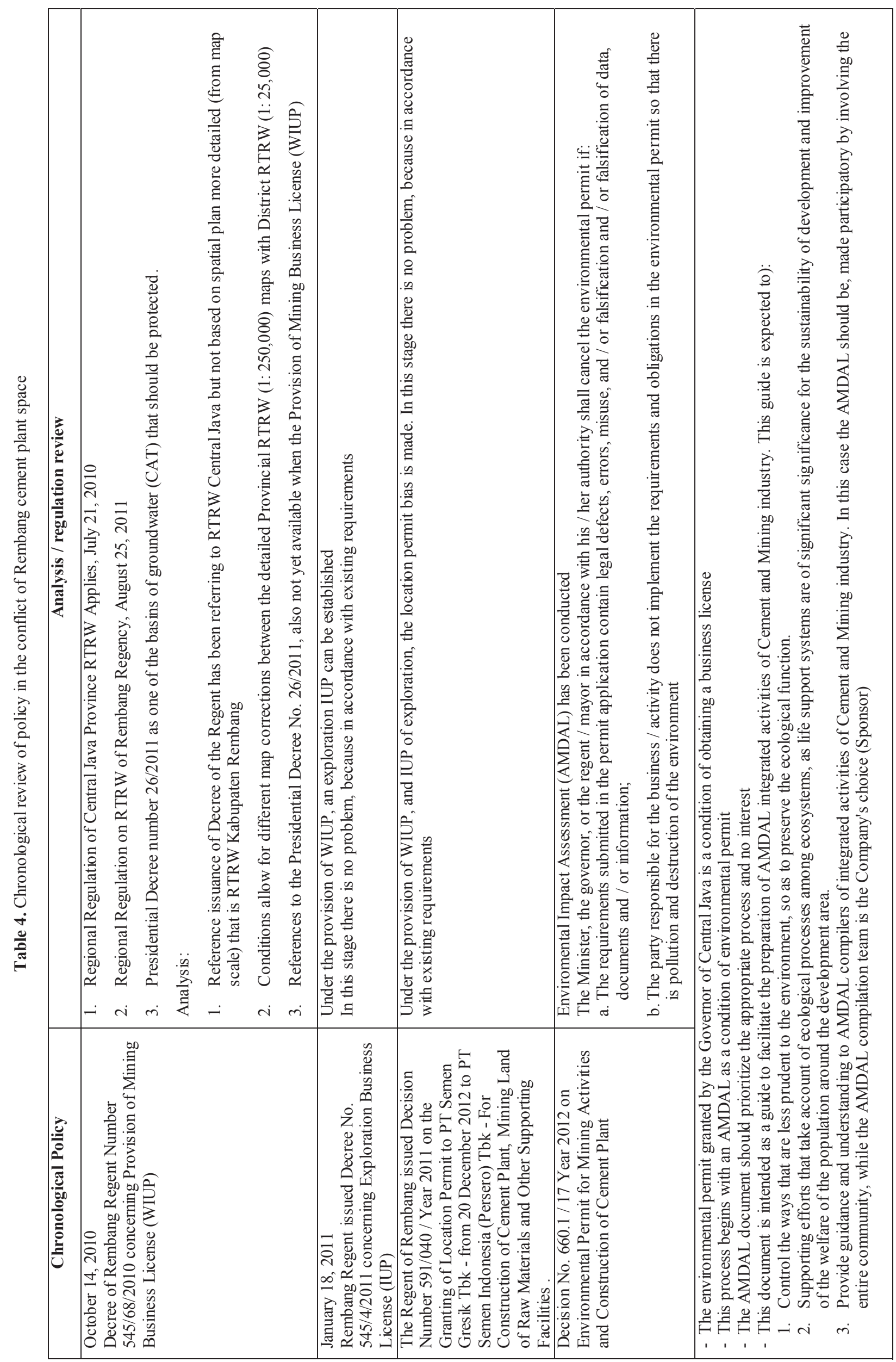




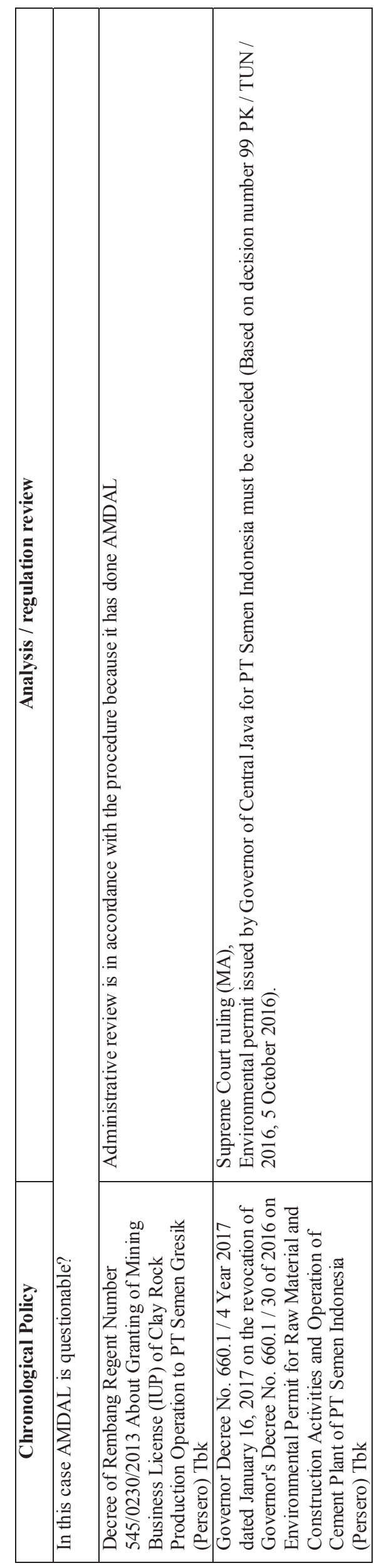




\subsection{Identify patterns of land change}

To see how big the land use change is in all of Rembang regency administration, it can be seen that the biggest change in the use of settlement land is $5,169 \%$ (increase from 2009-2015) then the loss of plantation land is $2,450 \%$ (shrink from 2009-2015). The following is the result of identification of land change pattern in Rembang regency.

Table 5. Identification of Land Use Change Pattern Year 2009 - Year 2015

\begin{tabular}{|l|l|c|}
\hline Classification of Land Use & $\begin{array}{c}\text { Land change } \\
\text { (Ha) }\end{array}$ & $\mathbf{\%}$ \\
\hline Industry and Tourism & 31.19 & $0.030 \%$ \\
\hline Garden & $-2,534.20$ & $-2.450 \%$ \\
\hline Forested Land & -6.59 & $-0.006 \%$ \\
\hline Open field & -11.22 & $-0.011 \%$ \\
\hline Waters & -43.84 & $-0.042 \%$ \\
\hline Plantation & -359.50 & $-0.348 \%$ \\
\hline Settlement & $5,346.39$ & $5.169 \%$ \\
\hline Dryland Agriculture & -0.03 & $0.000 \%$ \\
\hline Rice fields & $2,487.10$ & $2.405 \%$ \\
\hline Shrubs & -83.37 & $-0.081 \%$ \\
\hline
\end{tabular}

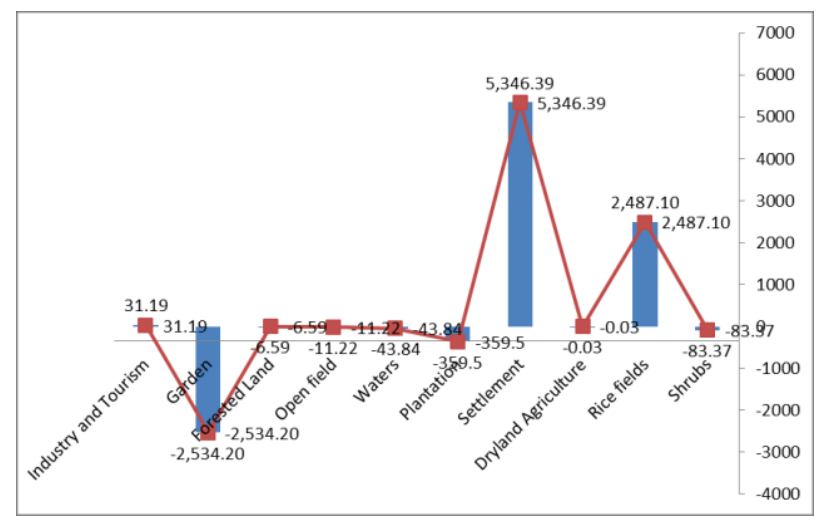

Fig. 3. Graph for the extent of land change Year 2009-2015 in Rembang Regency

\subsection{Identify deviations of land to RTRW}

Need to classify spatial pattern based on RTRW that is the function of protection and cultivation, as shown in the picture below.

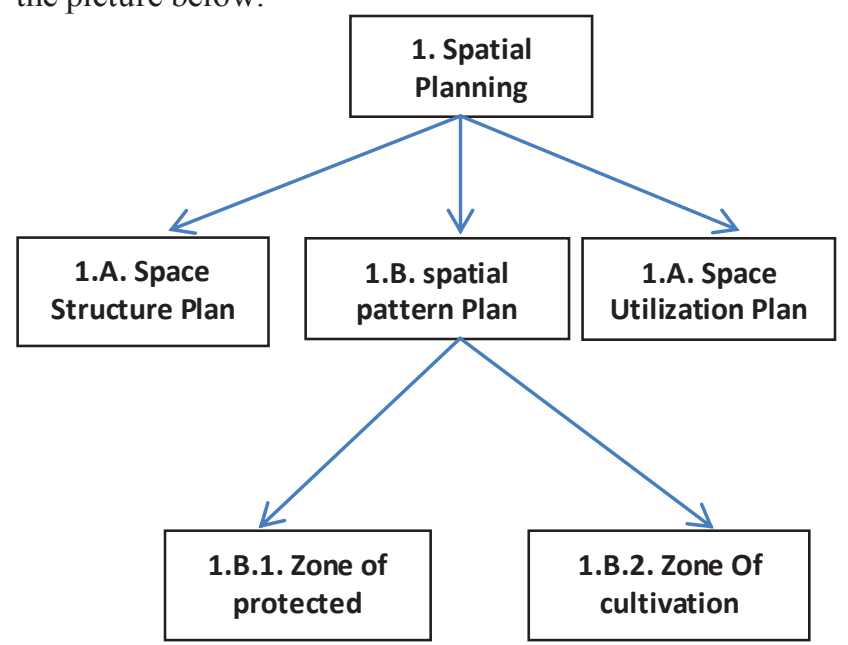

Fig. 4. Land classification based on spatial pattern RTRW
By integrating the land area of 2015 with the extent of the spatial pattern plan (land classification RTRW) the biggest change is in the function of wetland farming area of $58.88 \%$ of the total land change. Changes of concern are on protected functions such as 1) physiographic protected areas $(0.1 \%), 2)$ Protected forests $(4.43 \%)$, due to this function is to maintain environmental balance. Where this function is expected to be preserved / preservation.

Table 6. The area of deviation of land suitability with RTRW

\begin{tabular}{|l|c|c|}
\hline $\begin{array}{c}\text { Classification of Land Use } \\
\text { RTRW }\end{array}$ & $\begin{array}{c}\text { Land area not } \\
\text { in accordance } \\
\text { with the } \\
\text { RTRW }\end{array}$ & \% \\
\hline $\begin{array}{l}\text { Physiographic Protected } \\
\text { Areas }\end{array}$ & 625.50 & $0.10 \%$ \\
\hline Wetland Farming Area & $373,986.47$ & $58.88 \%$ \\
\hline Dryland Agricultural Area & $175,922.21$ & $27.70 \%$ \\
\hline $\begin{array}{l}\text { Area of Hard Crop } \\
\text { Agriculture }\end{array}$ & 106.21 & $0.02 \%$ \\
\hline Rural areas & $35,235.06$ & $5.55 \%$ \\
\hline Nature preserve & 77.68 & $0.01 \%$ \\
\hline Protected forest & $28,165.37$ & $4.43 \%$ \\
\hline Urban & $2,668.47$ & $0.42 \%$ \\
\hline Production forest & $11,509.94$ & $1.81 \%$ \\
\hline Limited production forest & $6,893.84$ & $1.09 \%$ \\
\hline Total & $635,190.74$ & $100.00 \%$ \\
\hline
\end{tabular}

\section{Conclusion}

Implementation of spatial planning (RTRW) on cases of economic and environmental space conflicts:

1) Overlap / decisions that precede existing policies or rules, such as granting WIUP permits by the Mayor. Where not yet based on RTRW Regional Regulation Rembang, and only based on RTRW Province with a scale of low level of accuracy. Similarly, there is no regulation of Presidential Decree number 26/2011.RTRW has not been able to respond explicitly to space for investment and space that must be protected environmentally

2) RTRW is prepared as if only to fulfill the requirements of Law no. 26 Year 2007, with the depth of the weak technical content due to the lack of data power and the lack of public participation in socialization.

Implementation of RTRW to change of spatial pattern between existing condition with spatial pattern plan

1) There is a shift in the pattern of space, especially in the function of protection, making the function of RTRW as a controlling tool was only at the level of documents and maps.

2) Weak supervision of the use of space, especially the function of protection causes RTRW not optimal.

3) RTRW should be a planning document according to the author here is a document that can be used in a long time or unlimited, so if the RTRW document is not necessarily in the continuous revision, unless there is a "force major" event. Especially for the 
function of protected areas must be properly preserved and strictly defined in the RTRW.

4) Given the complexity of the content of the RTRW document, it is appropriate that the local government in this case the provinces and municipalities should prepare good sectoral documents. Given the sectoral document, it can be used as the basis for preparing the RTRW.

5) Enhancement of supporting documents in the form of Strategic Environmental Assessment (SEA) as an integral part of RTRW document must be made with accuracy and applicable rules. The SEA document preparation should be separated from the part of the RTRW making activity to be more "independent" in providing input.

\section{References}

1. Wacana et al., 2008

2. De Genevraye and Samuel, 1972

3. Data base on: Regional Public Work Water Resources And Spatial Planning (DCKTR) Province of Central Java Year 2016

4. Rifa'I RS, Pertagunawan K. Biologi Perikanan 1. Penerbit CV Kayago, Jakarta (ID). (1983)

5. Edward and MSTarigan, Makara Sains 7,(2),8289(2003)

6. Salmin, Oksigen Terlarut (DO) Dan Kebutuhan Oksigen Biologi (BOD) Sebagai Salah Satu Indikator Untuk Menentukan Kualitas Perairan. Oseana, Volume XXX, Nomor 3, p. 21 - 26 (2005)

7. Sutimin, Model Matematika Konsentrasi Oksigen Terlarut Pada Ekosistem Perairan Danau. Jurusan Matematika, FMIPA, Universitas Diponegoro, Semarang (2006)

8. Peraturan Pemerintah No. 82. Pengelolaan Kualitas Air dan Pengendalian Pencemaran Air (2001) 